\title{
Peningkatan Aktifitas Kolaboratif Dan Hasil Belajar Siswa Melalui Guided Discovery Learning Berbantuan Puzzel
}

\author{
Awaluddin'), Siti Inganah²), Anis Farida Jamil'), Mayang Dintarini4), Dan \\ Zukhrufurrohmah' \\ 1awaluddin418@gmail.com \\ 22singanah@gmail.com \\ 3anisfarida@umm.ac.id \\ 4mayangdintarini@umm.ac.id \\ sukhrufurrohmah@umm.ac.id \\ ${ }^{1}$ SMAN 1 Batu Malang \\ 2,3,4,5 Program Studi Pendidikan Matematika, Universitas Muhammadiyah Malang
}

\begin{abstract}
Now a days, the government is promoting the Individual Learning Activity Sheet (UKBM) for student in mathematics learning. UKBM provides opportunities for students to study independently, and provides the chance for students to complete assignments (UKBM) differently for each student in one class. The aim of this study was to increase collaborative activity skills and student's learning outcomes through puzzle-assisted Guided Discovery Learning learning models. This study was a classroom action research within two cycles consisting of planning stage, implementation stage, observation stage, and reflection stage. The instruments used were observation sheets and test sheets. The teaching material is UKBM. The results of a guided discovery learning study assisted by puzzles with UKBM teaching materials there is an increase in student's collaborative abilities and learning outcomes.
\end{abstract}

Keywords: Guided Discovery Learning, Collaborative Ability, Learning Outcomes, Media Puzzle

\section{Pendahuluan}

Tujuan pendidikan tertera dalam UU mengenai Sistem Pendidikan Nasional No. 20 tahun 2003, yaitu "pendidikan Nasional berfungsi mengembangkan kemampuan dan membentuk watak serta peradaban bangsa yang bermartabat dalam rangka mencerdaskan kehidupan bangsa, bertujuan untuk berkembangnya potensi peserta didik agar menjadi manusia yang beriman dan bertakwa kepada Tuhan Yang Maha Esa, berakhlak mulia, sehat, berilmu, cakap, kreatif, mandiri, dan menjadi warga negara yang demokrasi serta bertanggung jawab". Tujuan nasional itu dicapai dengan adanya Kompetensi Inti dan Kompetensi Dasar untuk setiap unit pendidikan. Kompetensi ini adalah kompetensi standar standar atau minimal yang harus siswa miliki. Kompetensi ini disajikan di sekolah melalui pembelajaran. 
Widodo (2013) memaparkan bahwa pembelajaran seharusnya lebih mengarah pada aktivitas siswa untuk mendapatkan hasil belajar. Terdapat tiga aspek hasil belajar yang menjadi titik berat pembelajaran di sekolah saat ini, yaitu kognitif, psikomotor, dan afektif. Hasil belajar merupakan pola perilaku, pengertian, sikap, nilai, apresiasi dan keterampilan (Suprijono, 2012).

Pembelajaran hendaknya juga dapat menyiapkan siswa untuk bersosialisai dalam masyarakat. Hal tersebut dapat diwujudkan dengan mengasah kemampuan kolaboratif dan kooperatif siswa. Gokhale (1995) menyatakan bahwa konsep pembelajaran kooperatif, pengelompokkan dan pemasangan siswa untuk pencapaian dari suatu tujuan akademik. Hal ini telah ramai diteliti dan dikaji berdasarkan literatur profesional. Istilah pembelajaran kolaboratif merujuk pada metode pembelajaran dimana siswa dengan level tampilan berbeda, bekerja bersama dalam kelompok kecil menuju tujuan yang hendak dipakai. Siswa bertanggung jawab terhadap pemahaman teman satu kelompoknya. Jadi kesuksesan satu siswa akan membantu siswa lain untuk sukses juga.

Johnson \& Johnson (1986) mengatakan ada bukti yang meyakinkan bahwa tim kooperatif mendapatkan level berpikir lebih tinggi dan menyimpan informasi lebih lama daripada siswa yang bekerja sendiri. Dalam hal ini, kolaboratif merupakan istilah yang paling tradisional dari kooperatif. Sebenarnya, walaupun tidak ada kriteria mutlak, banyak orang membedakan kedua istilah ini. Terdapat beberapa kesepakatan yang mendefinisikan kooperatif sebagai bekerja sama dengan pembagian tugas yang akan mengarahkan ke tahap selanjutnya. Sedangakan kolaboratif adalah suatu proses kolektif dari awal, dimana semua siswa terlibat dalam penyajian/penyelesaian tugas (Roselli, 2016).

Berdasarkan wawancara kepada guru matematika sebelum penelitian didapatkan bahwa, penggunaan UKBM memberi siswa kesempatan belajar secara mandiri, dan siswa dapat menyelesaikan UKBM secara berbeda-beda setiap siswanya dalam satu kelas. Hal ini mempunyai keuntungan siswa dengan kognitif tinggi akan dapat segera menyelesaikan pelajaran dikelas tersebut, namun siswa dengan kognitif rendah bisa jadi menjadi terhambat, karena belum dapat menyelesaikan suatu kompetensi tertentu. Hal ini tentu menyebabkan beberapa siswa masih memiliki hasil belajar yang kurang memuaskan. Selain itu, guru juga memaparkan bahwa penggunaan media sangat jarang dilakukan dalam kelas.

Untuk memperbaiki proses pembelajaran di kelas, dalam hal ini, untuk menutupi kekurangan dalam penggunaan UKBM, maka dipilihlah topik ini dengan judul "PENINGKATAN KEMAMPUAN KOLABORATIF DAN HASIL BELAJAR SISWA 
Peningkatan Aktifitas Kolaboratif Dan Hasil Belajar Siswa Melalui Guided Discovery Learning Berbantuan Puzzel

Awaludin, Siti Inganah, Anis Farida Jamil, Mayang Dintarinni, dan Zukhufurrohmah

MELALUI MODEL GUIDED DISCOVERY LEARNING BERBANTUAN PUZZLE". Guided Discovery Learning Models dipilih karena dapat meningkatkan kemampuan kolaboratif serta hasil belajar siswa (Gokhale, 1995). Eggen \& Kauchak (2012) menyatakan dalam guided discovery learning guru memberikan siswa contoh suatu topik tertentu kemudian guru memandu siswa untuk memahami topik yang diberikan. Model ini kemudian dikombinasikan dengan media Puzzle, sehingga penerapannya akan lebih optimal untuk meningkatkan kemampuan kolaboratif siswa sekaligus meningkatkan hasil belajar siswa.

\section{Kajian Teori}

\subsection{Kemampuan Kolaboratif}

Pada pendahuluan telah dibahas mengenai konsep kolaboratif pada pembelajaran. Gokhale (1995) menyatakan bahwa konsep pembelajaran kooperatif, pengelompokkan dan pemasangan siswa untuk pencapaian dari suatu tujuan akademik. Istilah pembelajaran kolaboratif merujuk pada metode pembelajaran dimana siswa dengan level tampilan berbeda, bekerja bersama dalam kelompok kecil menuju tujuan yang hendak dipakai. Siswa bertanggung jawab terhadap pemahaman teman satu kelompoknya. Jadi kesuksesan satu siswa akan membantu siswa lain untuk sukses juga.

Johnson \& Johnson (1986) mengatakan bahwa tim kooperatif mendapatkan level berpikir lebih tinggi dan menyimpan informasi lebih lama daripada siswa yang bekerja sendiri. Terdapat dua istilah yang seringkali didengar yaitu Kooperatif dan Kolaboratif. Banyak orang membedakan kedua istilah ini. Kooperatif adalah bekerja sama dengan pembagian tugas yang akan mengarahkan ke tahap selanjutnya. Sedangakan kolaboratif adalah suatu proses kolektif dari awal, dimana semua siswa terlibat dalam penyajian/penyelesaian tugas (Roselli, 2016).

\subsection{Hasil Belajar}

Menurut Hudojo (dalam Suheri, 1999) hasil belajar adalah adanya peningkatan penguasaan materi pelajaran maupun pengalaman yang dimiliki siswa. Sedangkan menurut Supratiknya (2012) mengatakan bahwa hasil belajar merupakan kemampuan baru yang didapatkan siswa seusai mengikuti pembelajaran. Berdasarkan pengertian tersebut diketahui bahwa hasil belajar siswa dapat digunakan guru sebagai acuan untuk mengetahui penguasaan siswa terhadap materi yang telah diajarkan. Hasil belajar terlihat setelah proses belajar mengajar selesai. Melalui hasil belajar siswa, guru dapat 
mengevaluasi pembelajaran yang telah dilakukannya sehingga dapat menjadi bahan untuk perbaikan pembelajaran selanjutnya.

\subsection{Model Guided Discovery Learning}

Metode pembelajaran penemuan yang dikenalkan oleh Bruner ini telah menarik perhatian berbagai penelitian mengenai tujuan pembelajaran dan membandingkan berbagai bentuk metode pembelajaran penemuan. Menurut Mayer (2004:15) terdapat tiga jenis metode penemuan yaitu pure discovery method (metode penemuan murni), guided discovery method (metode penemuan terbimbing) dan expository method (metode eksplorasi). Pure discovery method atau selanjutnya disebut metode penemuan murni, mengharuskan siswa harus menemukan selesaian permasalahan tanpa ada atau sedikit bantuan dari guru. Guided discovery method atau selanjutnya disebut metode penemuan terbimbing, memberikan kesempatan siswa untuk menyelesaikan permasalahan yang diberikan dengan adanya bantuan, arahan atau timbal balik dari guru. Expository method atau selanjutnya disebut metode ekspositori merupakan metode ketika siswa diberikan permasalahan dan selesaian yang benar dari suatu permasalahan. Berbagai penelitian tersebut menyimpulkan bahwa penggunaan metode penemuan terbimbing memiliki dampak dan hasil yang sangat baik dibandingkan penggunaan penemuan sejati dan metode ekspositori (Mayer 2004:15).

Prasad (2011) menyatakan bahwa pembelajaran penemuan mendorong siswa membuat dugaan, memformulasi dugaan atau menemukan konsep kebenaran matematika dengan menggunakan proses induktif atau deduktif. Proses induktif merupakan proses menemukan kesimpulan berdasarkan hasil pengamatan pola atau observasi dan manipulasi tertentu. Deduktif merupakan manipulasi ide melalui penggunaan logika dalam memformulasikan kesimpulan.

Pada penelitian ini penemuan terbimbing merupakan serangkaian kegiatan yang dilakukan siswa untuk menemukan konsep kebenaran matematika dengan bimbingan guru sebagai fasilitator. Merujuk pada langkah penemuan Markaban (2008), langkahlangkah pembelajaran dengan strategi guided discovey yaitu: (1) identifikasi masalah; (2) mengumpulkan data; (3) membuat dugaan; (4) mengolah atau menganalisis data dan memverifikasi dugaan; (5) menyimpulkan dan (6) memecahkan masalah terkait hasil penemuan. Langkah identifikasi masalah yang dimaksud dapat berupa pemberian pertanyaan-pertanyaan yang dimaksudkan untuk merangsang keingintahuan siswa, mengingatkan siswa pada materi sebelumnya yang berkaitan dengan materi yang akan dipelajari atau mengarahkan siswa pada konsep yang akan ditemukan. Dari permasalahan 
Peningkatan Aktifitas Kolaboratif Dan Hasil Belajar Siswa Melalui Guided Discovery Learning Berbantuan Puzzel

Awaludin, Siti Inganah, Anis Farida Jamil, Mayang Dintarinni, dan Zukhufurrohmah

yang diberikan, siswa diminta mengumpulkan data untuk membuat dugaan. Kegiatan mengumpulkan data dilakukan malalui kegiatan mengamati, memproses atau menganalisis data yang berikan. Selanjutnya hasil pengolahan atau analisis dari pengumpulan data diwujudkan dalam bentuk dugaan oleh siswa pada langkah membuat dugaan. Kegiatan selanjutnya adalah memverifikasi dugaan melalui kegiatan menguji dugaan dengan mengambil contoh permasalahan lainnya yang sejenis atau dengan melakukan analisis dan pengolahan data secara cermat. Langkah menyimpulkan merupakan kegiatan siswa menegaskan kebenaran dugaannya yang telah dibuat. Kegiatan setelah menyimpulkan adalah memecahkan permasalahan terkait konsep yang ditemukan.

\section{Metode Penelitian}

Penelitian ini adalah kualitatif dengan jenis penelitian PTK (Penelitian Tindakan Kelas). Bentuk penelitian ini adalah penelitian kolaboratif dimana memerlukan kerjasama antara peneliti dan guru dalam kesamaan pemahaman dan kesepakatan tindakan. Indikator keberhasilan dilihat dari peningkatan kemampuan kolaboratif dan hasil belajar siswa SMA melalui Guided Discovery Learning Berbantuan Media Puzzle.

Subjek penelitian adalah siswa kelas XI MIPA 6 SMA Negeri 1 Batu dengan 37 siswa. Bahan ajar yang digunakan pada pembelajaran adalah UKBM. Instrumen yang digunakan pada penelitian ini berupa lembar observasi aktivitas kolaboratif siswa, lembar observasi aktivitas guru, kamera video (dokumentasi) dan lembar tes. PTK ini dilakukan dalam dua siklus, dimana masing-masing siklusnya terdiri dari 4 tahap 1) Tahap Perencanaan, 2) Tahap Tindakan, 3) Tahap Observasi, dan 4) Tahap

Refleksi. Teknik analisis data hasil penelitian menggunakan teknik analisis data kualitatif dan kuantitatif yaitu reduksi data, penyajian data, dan penyimpulan yang didukung dengan perhitungan skor siswa.

\section{Hasil Dan Pembahasan}

Tahap perencanaan pada siklus pertama dilaksanakan dengan merancang perangkat pembelajaran yang akan digunakan. Perangkat yang disiapkan meliputi RPP berciri guided discovery, modul pembelajaran materi persamaan trigonometri berciri guided discovery, dan media Puzzle.

Pada pelaksanaan tindakan, pembelajaran dilaksanakan sesuai langkah pembelajaran guided discovery dan dipandu dengan modul pembelajaran berciri guided discovery dengan alokasi waktu seriap pertemuan adalah $2 \times 45$ menit. Pada langkah pertama guru 
mengajak siswa mengingat kembali bentuk grafik fungsi trigonometri dan aplikasi grafik trigonometri dalam kehidupan sehari-hari. Setelah mengingat bentuk grafik trigonometri, siswa duduk dengan kelompok. kegiatan diskusi kelompok diawali dengan secara bersama menyusun Puzzle hingga membentuk suatu grafik fungsi trigonometri. Kegiatan menyusun Puzzle dilanjutkan dengan melengkapi pasangan titik titik yang sesuai dengan grafik yang telah dibuat. Pada langkah mengumpulkan data ini, setelah mengidentifikasi masalah dengan menyusun Puzzle, siswa diharapkan menemukan keterkaitan antara titik pada domain dan pasangannya di kodomain. Selanjutnya siswa diminta menuliskan dugaannya mengenai keterkaitan nilai pada domain dan kodomain serta berdasar temuan pada kegiatan sebelumnya. Setelah siswa menuliskan dugaan, guru membimbing siswa menguji hasil dugaannya kemudian dilanjutkan dengan menyimpulkan.

Selama kegiatan pembelajaran, dilakukan observasi oleh 2 observer untuk menilai kolaboratif siswa, baik dengan anggota dalam satu kelompok maupun kegiatan kolaboratif dengan kelompok lain. Penilaian kolaboratif berdasar indikator pada lembar observasi. Berdasar hasil observasi, kegiatan pembelajaran berciri guided discovery terlaksana dengan baik sesuai langkah yang telah ditetapkan. Sedangkan aktivitas kolaboratif siswa mencapai rerata skor 3,4. Hasil rerata skor pada siklus pertama menunjukkan kemampuan kolaboratif siswa adalah sangat baik. Hasil tes pada siklus pertama menunjukkan bahwa 13 dari 28 siswa memperoleh nilai di bawah KKM. Hasil tes siswa secara klasikal ditunjukkan pada Tabel 1 di bawah ini. Pada pelaksanaan tes, nilai tes yang digunakan sebagai data adalah 28 siswa. Jumlah 28 siswa dipilih berdasarkan kehadiran siswa selama Siklus 1 dan Siklus 2.

Tabel 1. Nilai Tes Siswa Pada Siklus 1

\begin{tabular}{llll}
\hline No. & Kategori & Jumlah Siswa & Persentase \\
\hline 1 & Nilai Tes Siswa $>$ KKM & 13 & $46 \%$ \\
\hline 2 & Nilai Tes Siswa $\leq$ KKM & 15 & $54 \%$ \\
\hline
\end{tabular}

Pada langkah refleksi dilakukan evaluasi berdasar hasil observasi dan nilai tes yang diperoleh pada siklus pertama. Berdasar hasil refleksi, langkah pada modul dibuat lebih rinci terutama pada langkah mengidentifikasi masalah dan mengumpulkan data. Bantuan media Puzzle sudah cukup baik untuk memunculkan kolaboratif siswa sehingga Puzzle tetap dugunakan. Hasil observasi juga menunjukkan bahwa penggunaan dua meja saja dalam satu kelompok lebih efektif dibandingkan 4 meja. Selain kegiatan identifikasi masalah dan diskusi kelompok, perbaikan yang dilakukan adalah menegaskan simpulan yang diperoleh dibantu dengan membahas beberapa permasalahan. Berdasar hasil 
Peningkatan Aktifitas Kolaboratif Dan Hasil Belajar Siswa Melalui Guided Discovery Learning Berbantuan Puzzel

Awaludin, Siti Inganah, Anis Farida Jamil, Mayang Dintarinni, dan Zukhufurrohmah

observasi dan hasil tes pada siklus pertama, direncanakan siklus kedua karena belum ada peningkatan aktifitas kolaboratif dan hasil belajar siswa.

Pelaksanaan siklus 2 dimulai dengan perencanaan pembelajaran yang akan dilakukan. Berdasar hasil refleksi, pelaksanaan siklus kedua dilaksankan sesuai langkah pembelajaran guided discovery dengan memperhatikan aspek identifikasi masalah dan pengumpulan data. Kegiatan diskusi kelompok diatur dengan menggunakan 2 meja dalam satu kelompok.

Pada pelaksanaan pembelajaran siklus kedua, guru melaksanakan pembelajaran sesuai dengan langkah pembelajaran pada guided discovery dan menggunakan modul persamaan trigonometri berciri guided discovery. Alokasi waktu yang digunakan setiap pertemuan sama dengan alokasi waktu pada Siklus pertama yaitu $2 \times 45$ menit. Pada tahap identifikasi masalah, siswa diminta untuk kembali mengingat materi sebelumnya dan diminta untuk menyelesaikan beberapa permasalahan terkait materi pada pertemuan sebelumnya. Setelah menyusun Puzzle sesuai dengan fungsi yang diberikan, siswa menyelesaikan kegiatan pada langkah mengumpulkan data. Kegiatan selanjutnya setelah mengumpulkan data adalah membuat dugaan. Langkah membuat dugaan dilanjutkan dengan menyimpulkan. Kegiatan menyimpulkan di lanjutkan dengan menyelesaikan soal yang berkaitan dengan materi yang dipelajari.

Observasi dilakukan oleh 2 observer yang mengamati tentang kolaboratif siswa dalam menyelesaikan serangkaian kegiatan pembelajaran berciri guided discovery. Pada tahap akhir disetiap siklus dilaksanakan tes guna mengetahui hasil belajar siswa pada siklus $\mathbf{1}$. Berdasar hasil obervasi diperoleh skor rerata 3,7 yang menunjukkan bahwa kemampuan kolaboratif siswa sangat baik. Berikut merupakan hasil tes siswa pada siklus 2 .

Tabel 2. Hasil Tes Siswa pada Siklus Kedua

\begin{tabular}{llll}
\hline No. & Kategori & Jumlah Siswa & Persentase \\
\hline 1 & Nilai Tes Siswa $>$ KKM & 20 & $53 \%$ \\
\hline 2 & Nilai Tes Siswa $\leq$ KKM & 8 & $47 \%$ \\
\hline
\end{tabular}

Hasil observasi kemampuan kolaboratif siswa meningkat dari skor rerata 3,4 menjadi 3,7 sehingga dapat disimpulkan bahwa tujuan pelaksanaan Tindakan Kelas telah tercapai. Hasil tes siswa pada akhir siklus 2 telah menunjukkan adanya peningkatan hasil belajar dari siklus 1 ke siklus 2. Di siklus 1, sebanyak 13 siswa mencapai nilai di atas KKM, dengan KKM 80. Di siklus 2 sebanyak 20 siswa mencapai nilai di atas KKM. Tabel 3 di bawah menunjukkan perbedaan pada siklus pertama dan siklus kedua. 
Tabel 3. Perbandingan Hasil Siklus 1 dan Siklus 2

\begin{tabular}{llll}
\hline No. & Aspek & Siklus 1 & Siklus 2 \\
\hline 1 & Skor Kemampuan Kolaboratif & 3,4 & 3,7 \\
\hline 2 & Hasil Tes Siswa $>$ KKM & $46 \%$ & $53 \%$ \\
\hline 3 & Hasil tes Siswa $\leq$ KKM & $54 \%$ & $47 \%$ \\
\hline
\end{tabular}

Berdasar hasil siklus kedua diketahui bahwa perubahan yang dilakukan memberikan dampak pada pembelajaran. Temuan yang diperoleh diantaranya adalah, untuk meningkatkan kemampuan kolaboratif siswa, meja kelompok yang digunakan cukup 2 meja atau satu meja panjang dengan jumlah anggota kelompok 4 sampai 5 siswa. Penggunaan meja yang banyak dapat mengakibatkan jarak antar anggota kelompok sehingga siswa cenderung malas untuk berkomunikasi dengan anggota kelompok lainnya. Penggunaan media pembelajaran bertipe Puzzle sangat menarik minat siswa sehingga setiap anggota tertarik untuk ikut serta dalam kegiatan menyusun Puzzle pada langkah identifikasi masalah.

Berdasar hasil pada siklus kedua dapat disimpulkan bahwa pelaksanaan pembelajaran melalui guided discovery berbantuan media puzzle dapat meningkatkan aktifitas kolaboratif dan hasil belajar siswa pada materi persamaan trigonometri. Hasil penelitian ini sejalan dengan hasil penelitian Qomariyah (2014) menyimpulkan bahwa dengan pembelajaran guded discovery yang efektif dapat meningkatkan keterampilan proses sains siswa. Suhendri (2013) juga menyimpulkan berdasar penelitiannya bahwa hasil belajar meningkat dengan penerapan model pembelajaran konstruktif berbasis penemuan terbimbing.

\section{Referensi}

Eggen, P. \& Kauchak, D. (2012). Strategi dan Model Pembelajaran. Jakarta: PT Indeks. Gokhale, A. A. (1995). Collaborative Learning Enhances Critical Thinking, 7(1) 22-30.

terbimbing Huri, Suhendri. 2013. Penerapan Model Pembelajaran Konstruktif Berbasis penemuan dalam Meningkatkan Hasil Belajar Matematika. 2013. Formatif: Jurnal Ilmiah Pendidikan MIPA, Vol 3, No 32013.

Johnson, R.T., \& Johnson, D. W. (1986). Action research: Cooperative learning in the science classroom. Science and Children, 24, 31-32.

Qomariyah, Nur. (2014). Penerapan Model Pembelajaran Guided Sicovery untuk meningkatkan katerampilan proses sains siswa SMP kelas VII. 2014, E-Jurnal Pendidikan SAins Vol 2 No 1

Roselli, N. D. (2016). Collaborative learning: Theoretical foundations and applicable strategies to university, 4. 
Peningkatan Aktifitas Kolaboratif Dan Hasil Belajar Siswa Melalui Guided Discovery Learning Berbantuan Puzzel

Awaludin, Siti Inganah, Anis Farida Jamil, Mayang Dintarinni, dan Zukhufurrohmah

Supratiknya. 2012. Penilaian Hasil Belajar dengan Teknik Nontes. Jogjakarta: Universitas Sanata Darma.

Suprijono, A. (2012). Cooperative Learning: Teori dan Aplikasi PAIKEM. Yogyakarta: Pustaka Belajar.

Widodo, L. W. (2013). PROBLEM BASED LEARNING PADA SISWA KELAS VIIA MTs NEGERI DONOMULYO KULON PROGO TAHUN PELAJARAN 2012 / 2013, XVII(April), 32-35. 